\title{
INTERAKSIONISME SIMBOLIK SANTRI TERHADAP KIAI MELALUI KOMUNIKASI DI PONDOK PESANTREN AL MUNAWWIR KRAPYAK YOGYAKARTA
}

\author{
M. Hamam Alfajari \\ Alumnus Ilmu Komunikasi Fakultas Ilmu Sosial dan Humaniora \\ UIN Sunan Kalijaga Yogyakarta \\ hamamalfajari@gmail.com
}

\begin{abstract}
This research aims to determine the perspective of symbolic interactionism students to kiai in the communication process in Al Munawwir Islamic Boarding School Krapyak Yogyakarta. To achieve the objectives of the study, researchers used a qualitative approach, with qualitative descriptive type. The subjects in this study were students at Al Munawwir Boarding School Krapyak Yogyakarta. Data retrieval is done through interviews and observation. Results found is that symbolic interactionism students are not deterministic. That is, what is done by the students of the kiai is a subjective awareness of students who interpret certain symbols through interaction. The fact then that creates a social world for students. Social world that includes an appearance, gestures and symbolic language emerged in social situations, so in this context, the social world at the boarding school students can be said is a product of individuals as actors who are active.
\end{abstract}

Keywords: Symbolic Interactionism, Communication, Islamic Boarding School.

\begin{abstract}
Abstrak
Penelitian ini bertujuan untuk mengetahui perspektif interaksionisme simbolik santri terhadap kiai dalam proses komunikasi di Pondok Pesantren Al Munawwir Krapyak Yogyakarta. Untuk mencapai tujuan penelitian ini, peneliti menggunakan pendekatan kualitatif, dengan jenis deskriptif kualitatif. Subyek dalam penelitian ini adalah santri di Pondok Pesantren Al Munawwir Krapyak Yogyakarta. Sementara pengambilan data dilakukan melalui wawancara dan observasi. Hasil yang ditemukan adalah bahwa interaksionisme simbolik santri tidak bersifat deterministik. Artinya, apa yang dilakukan oleh santri kepada kiai adalah kesadaran subjektif santri yang menafsirkan simbol-simbol tertentu melalui interaksi. Bahkan kemudian yang menciptakan dunia sosial bagi santri. dunia sosial yang meliputi penampilan, perilaku, dan bahasa simbolik muncul dalam situasi sosial, sehingga dalam konteks ini, dunia sosial pada santri pondok pesantren dapat dikatakan adalah produk individu sebagai aktor yang aktif.
\end{abstract}

Kata Kunci: Interaksionisme Simbolik, Komunikasi, Pondok pesantren 


\section{PENDAHULUAN}

Pondok pesantren merupakan sebuah lembaga yang bisa dikatakan sebagai kerangka sistem pendidikan islam tertua di Indonesia. Secara historis, pondok pesantren bukan saja identik dengan makna keislaman, akan tetapi juga mengandung makna terhadap nilai-nilai keaslian Indonesia. Nurcholish Majid (1997: 10) dalam bukunya berjudul Bilik-bilik Pesantren mengatakan bahwa pondok pesantren merupakan artefak peradaban yang dibangun sebagai institusi pendidikan bercorak tradisional, unik, dan indigenious. Ketika berbicara mengenai pondok pesantren, tidak akan terlepas dari sosok kiai dengan santri sebagai bagian dari elemen pondok pesantren.

Kepemimpinan kharismatik seorang kiai di pondok pesantren dapat menjadi pioner sistem pendidikan islam di Indonesia. Kiai memiliki kemampuan dalam memperoleh dan mempertahankan otoritasnya. Sehingga kiai dapat dengan mudah menggerakan, mengarahkan, menginspirasi, dan mengontrol semua unsur di dalam pondok pesantren. Model kepemimpinan kiai semacam ini tidak terlepas dari adanya proses interaksi yang terjadi antara kiai dengan santri pondok pesantren. Pola interaksi para santri dengan kiai dapat dikategorikan ke dalam hubungan dialektik, yaitu hubungan di mana orangorang yang berhubungan akan saling memberikan pengaruh dan akibat.

Saat santri berkomunikasi dengan kiainya akan sangat bergantung pada norma, nilai, budaya dan aturan yang berlaku, termasuk karena adanya campur tangan setiap elemen di pondok pesantren. Akan tetapi, karena hal demikian juga dibentuk melalui proses komunikasi, maka bagaimana proses komunikasi itu berlangsung dapat mencerminkan situasi sosial di pondok pesantren tersebut.

Struktur komunikasi yaitu sistem yang terbentuk dalam proses komunikasi, yakni ketika proses komunikasi berlangsung cukup lama menurut norma maupun nilainilai, serta memberi efek tertentu (Nina Syam, 2009: 14). Komunikasi mengambil peran untuk membangun hubungan para santri dengan kiai. Sebagai sebuah proses, komunikasi mentransfer simbol-simbol yang mengandung makna. Untuk itu, kiai bersama simbol-simbol yang melekat dalam dirinya, kemudian diterjemahkan atau ditafsirkan oleh para santri melalui proses komunikasi sehingga membentuk tatanan sosial khas pondok pesantren.

Komunikasi melalui simbol-simbol merupakan isyarat yang mempunyai arti khusus (makna yang dapat dimengerti) serta muncul dalam diri individu lain yang memiliki ide sama. Komunikasi yang terjadi bukan saja melibatkan pesan verbal seperti kata, frasa atau kalimat, akan tetapi proses komunikasi tersebut juga melibatkan proses pertukaran simbol yang bersifat nonverbal berupa isyarat, ekspresi wajah, kontak mata, bahasa tubuh, dan sentuhan sehingga dirisang aktor yang terlibat dalam proses tersebut mampu untuk membacanya (Umiarso dan Elbandiansyah, 2014: 214).

Penelitian ini menggunakan pendekatan teori interaksionisme simbolik sebagai pisau analisis untuk memahami interaksi santri dengan kiai.Simbol-simbolinimerupakansesuatu yang digunakan dalam berkomunikasi untuk menyampaikan pesan yang dimaksud olehaktor. Proses memahami simbol tersebut adalah bagian atau memang merupakan proses penafsiran dalam berkomunikasi.

George Herbert Mead mengatakan teori interaksi simbolik sebagai cara manusia dalam berinteraksi melalui simbol-simbol yang dapat berupa kata, gerak tubuh, nilai, norma, dan peran. Untuk itu, komunikasi yang terjalin secara pribadi bukan karena didasarkan tindakan pribadinya, melainkan karena keanggotan dirinya dalam kelompok masyarakat (Umiarso dan Elbandiansyah, 2014: 63).

Gagasan mendasar yang menjadi sumber telaahnya yakni bahwa komunikasi terjadi melalui dunia simbol yang saling berkaitan, lalu konsep diri terbentuk melalui komunikasi, sehingga aktivitas sosial menjadi mungkin melalui proses pengambilan peran orang lain sebagaimana layaknya sandiwara dalam berkomunikasi. Ruang 
lingkup perspektif interaksionisme simbolik tetap memberikan tekanan pada simbol dan pertukaran simbol yang menciptakan makna bersama. Individu tidak dapat memahami konsep diri dalam berkomunikasi apabila tidak dimulai dari memahami masyarakat di sekelilingnya (Nina W. Syam, 2009: 26-28).

Tulisan ini bertujuan untuk mengetahui bagaimana interaksionisme simbolik santri terhadap kiai melalui komunikasi di Pondok Pesantren Al Munawwir Krapyak Yogyakarta. Unit analisis teori adalah simbolik, diri (self), berpikir (mind), interaksi sosial, dan dunia sosial.

\section{METODE}

Penelitian ini menggunakan pendekatan kualitatif dengan tipe penelitian deskriptif. Dalam penelitian kualitatif, analisis data tidak mementingkan angka atau kuantifikasi fenomena. Maka kemudian peneliti berusaha mendeskripsikan secara seksama dan mengkaji sejumlah variabel seputar interaksionisme simbolik santri terhadap kiai di Pondok Pesantren Al Munawwir Krapyak Yogyakarta dalam berkomunikasi.

Pengumpulan data penelitian ini melalui wawancara mendalam dengan cara bertatap muka secara langsung dengan informan, sementara peneliti berperan sebagai instrumen utama penelitian. Disamping itu, peneliti juga melakukan observasi non partisipan, hanya sebagai pengamat tanpa terlibat secara langsung aktifitas informan.

Selanjutnya data penelitian yang terkumpul akan dianalisis menggunakan teknik analisis data interaktif Miles dan Huberman. Teknik ini pada dasarnya terdiri dari reduksi data, penyajian data, dan penarikan serta pengujian kesimpulan.

\section{HASIL DAN PEMBAHASAN}

\section{Makna Simbolik Menurut Santri}

Pendekataan teori interaksi simbolik berfokus pada cara manusia dalam berinteraksi melalui simbol-simbol yang ditafsirkan. Komunikasi yang terjadi bukan saja melibatkan simbol-simbol verbal seperti kata, frasa atau kalimat, akan tetapi proses komunikasi tersebut juga melibatkan proses pertukaran simbol yang bersifat non verbal seperti isyarat, ekspresi wajah, kontak mata, bahasa tubuh, dan sentuhan sehingga dirisang aktor yang terlibat dalam proses tersebut mampu untuk membacanya. Untuk itu, komunikasi yang terjalin secara pribadi bukan karena didasarkan tindakan pribadinya, melainkan karena keanggotan dirinya dalam kelompok masyarakat (Umiarso dan Elbandiansyah, 2014: 214).

Santri yangsangat menghormati dan mengidolakan kiainya di Pondok Pesantren Al Munawwir Krapyak Yogyakarta merupakan peristiwa simbolik akibat dari pemaknaan santri terhadap simbol-simbol di lingkungan santri berada. Kiai bagi santrinya adalah adalah ulama, guru, sekaligus orangtua di pondok pesantren. Kiai menjalankan tugas dan fungsi sebagaimana orangtua yang selalu melindungi, membimbing, dan menasihati para santri. Selain itu, kiai juga disimbolkan sebagai agent of social change dalam kehidupan masyarakat.

“Kiai yang pertama adalah sebagai
guru, juga sebagai orangtua. Kedua,
kiai adalah orangalim yang mengontrol
kondisi lingkungan sosial di sekitarnya.
Karena kalau di suatu tempat ada
sosok kiai, maka akan lebih terkontrol,
sehingga lebih berjasa bagi masyarakat
sekitar. Coba aja misalkan dalam suatu
daerah tidak ada sosok kiai, mungkin
kita akan merasakan satu peran yang
hilang. Istilahnya kiai itu pakunya
bumi”(informan 1,pada 26 September
2o15, di Krapyak, Bantul)
“...sampai kapanpun, kiai adalah guru
dan sekaligus orangtua bagisaya.
Sehingga saya sudah menyerahkan diri
kepada kiai supaya ilmu yang diperoleh
mendapat barokah” (Informan 3, pada
2 Juli 2o15, di Krapyak, Bantul).

Guru adalah teladan bagi murid (santri), oleh karenaitu sifat, kepribadian, dan tindakan seorang kiai akan menjadi contoh bagi murid-muridnya, bahkan oleh masyarakat. Selanjutnya santri memaknai 
kiai sebagai sosok layaknya orangtua. Kiai menggantikan peran orangtua bagi santri saat berada di pondok pesantren. Kiai menjalankan tugas dan fungsi sebagai orangtua yang selalu melindungi, membimbing, dan menasihati para santri. Kiai juga disimbolkan sebagai agent of social change dalam kehidupan masyarakat. Artinya, bahwa dalam kehidupan sosial, peran kiai tidak dapat dikesampingkan sebagai penjaga moralitas masyarakat. Sehingga santri, termasuk masyarakat secara sukarela akan menyerahkan dirinya kepada kiai agar membimbing ke jalan yang lurus.

Selain itu, melupakan ikatan dengan kiai dianggap sebagai satu kesalahan yang tidak seharusnya terjadi karena dapat menghilangkan berkah kiai. Akibat selanjutnyadarikehilanganberkahkiaiadalah pengetahuan santri tidak akan bermanfaat. Misalnya ketika santri di kemudian hari memimpin sebuah pondok pesantren, maka ia tidak akan dapat menarik santri yang banyak, atau kalah dibandingkan dengan teman-temannya yang tidak melupakan hubungan dengan kiai.

“...kalau di pesantren seperti ini (salaf), ikatan santri dengan kiai tidak ada habisnya, bahkan sekalipun sudah jadi alumni, tetap terikat meskipun sudah tua. Tidak ada istilah mantan santri. Sebab santri itu yaa sampai kapan pun santri. meskipun santri sudah keluar dari pondok pesantren, ikatan santri dengan kiainya tetap harus dijaga. Misalkan sowan ketika ada waktu luang" (Informan 2, pada 26 September 2015, di Krapyak, Bantul)

"Santri sampai kapanpun ya tetap santri. Tidak boleh ada istilah mantan santri dari kiai A, misalnya. Sebab memutus ikatan santri dengan kiai adalah suatu tindakan yang sangat disesalkan. Itu samasaja kita (santri) tidak tahu terimakasih. Dulu sudah dibimbing,dinasihati, dan mendapat banyakpelajarandarikiai,kokkemudian setelah lulus tidak mengenang jasajasa para kiainya. Bisa tidak berkah hidupnya" (Informan 4, pada 2 Juli 2015, di Krapyak, Bantul)
Bagi santri merupakan satu hal yang "tabu" ketika mengatakan bahwa ia adalah "bekas" santri dariseorang kiai tertentu. Oleh karena itu, ketika seorang santri menjadi muridkiai tersebut, maka seumur hidupnya akan tetap menjadi muridnya.

Apayang disampaikan diatas merupakan implikasi dari penafsiran dan pemaknaan santri terhadap kiainya. Santri telah melakukan internalisasi berupa penafsiranpenafsiran terhadap simbol-simbol. Ketika penafsiran yang sudah menjadi keyakinan bagi santri, makaapa dan bagaimanatindakan santri terhadap kiainya akan sebagaimana penafsiran tersebut. Melalui proses penafsiran ini kemudian santri memiliki persepsi terhadap kiainya, yang menjadi acuan bagi santri untuk memperlakukan kiai sebagaimana yang dipersepsikan. Ini sesuai dengan ide dasar teori interakisionisme simbolik bahwa manusia bertindak atau bersikap terhadap orang lain dilandasi atas pemaknaan kepada orang lain, kemudian pemaknaan-pemaknaan itu muncul dari interaksi sosial yang dipertukarkan di antara manusia.

\section{Pikiran (mind) dan Konsep Diri (self) Santri}

Santri sebelumnya memang sudah memiliki beragam informasi tentang kiainya yang masuk ke dalam dirinya atau disebut sebagai fase internalisasi. Memori tentang kiai sudah terekam melalui pengalamanpengalaman di masa lalu. Sehingga terjadi proses pengembangan diri (self) terhadap lingkungan sosial di mana santri berada.

Ada beberapa media bagi santri untuk mendapatkan informasi-informasi tentang kiainya, yang kemudian informasi tersebut mengendap menjadipersepsi bagi santri dan menjadi rujukan utama tentang bagaimana sebaiknya memperlakukan kiainya. pertama, santri mendapatkan informasi secara langsung dari kiai sehingga santri mengenal sosok kiainya.

“...misalkan pengalaman saya ketika sowan ke kiai, biasanya memang yang lebih aktif kiainya ketimbang 
santri. Kecuali ketika santri punya hajat tertentu, maka santri akan menyampaikan hajat tersebut, kemudian mendengarkan secara seksama nasihat atau arahan dari kiai..." (Informan 3, pada 26 September 2015, di Krapyak, Bantul)

"Karena memang saya melihat santri senior, mereka melakukan seperti itu. Ternyata kalau di pondok-pondok tradisional lebih condong sebagai bentuk tadzim kepada kiainya. Mereka merujuk kepada kitab klasik. Dalam kitab itu disebutkan, kalau ilmu kamu ingin bermanfaat, maka muliakanlah ilmunya dan muliakan kiai. Akan tetapi dalam tanda petik, yakni tetap ada batasan untuk tidak terlalu menyanjung atau mengkultuskan kiai, sebab kita sama-sama manusia..."(Informan 1, pada 26 September 2015, di Krapyak, Bantul)

George Herbert Mead menambahkan bahwa individu-individu di dalam lingkungan sosial tidak dilihat sebagai unit-unit yang termotivasi oleh kekuatan-kekuatan eksternal dan internal di luar kendali mereka, ataudi dalam batas-batas suatu struktur yang kurang lebih tetap. Melainkan lebih tepatnya, individu-individu tersebut sebagai unit-unit reflektif atau berinteraksi yang membentuk entitas masyarakat (George Ritzer, 2012:626). Artinya, kemampuan berpikir mampu membuat seseorang bertindak secara reflektif daripada hanya sekedar tindakan secara tidak reflektif. Ada proses interaksi dengan diri sendiri sebelum melakukan suatu tindakantertentu.

"Santri itu seseorang yang belajaragama sambil tinggal di pesantren atau asrama. Dengar kata santri, biasanya dalam konteks pemahaman agamanya lebih kuat. Sementara itu jika dilahat dalam konteks bagaimana santri berpakaian? Kalau saya pribadi, santri itu ya nggak mesti pakai sarung. Fleksibel aja, sesuai kondisi lingkungannya, melihat tempat dan acaranya seperti apa. Jadi, misalkan mau pakai celana ataupun sarung dan peci, ya sah-sah saja” (Informan 3, pada 26 September 2015, di Krapyak, Bantul)
"Santri adalah orang yang mengikuti peraturan kiai di pondok pesantren, karena kita jauh dari orang tua. Kedekatan diantara santri seperti nggak ada batas. Kalau ada makanan, ya dimakan bareng. Tidur juga bareng. Terus cara berpakaian santri juga biasanya sopan, memakai sarung dan peci. Jadi kalau selesai sekolah, harus pake sarung. Itu sudah peraturan, dan kami ya mematuhi peraturan itu. Meskipun sebenarnya kami juga dibebaskan dalam hal berpakaian, artinya tidak mesti memaki sarung dan peci terus, misalkan pakai kaos juga boleh, asalkan tau tempat" (Informan 4, pada 28 September 2015, di Krapyak, Bantul)

Dengan demikian diri (self) santri merupakan bentuk definisi kepada kiainya, situasi, objek, dan bahkan kepada diri santri sendiri yang kemudian menentukan tindakannya. Namun, yang perlu digarisbawahi bahwa tindakan diri (self) santri tidak dapat digolongkan sebagai kebutuhan, dorongan, impuls, tuntutan budaya atau tuntutan peran, melainkan tindakan santri hanya didasarkan pada definisi atau penafsiran santri atas objekobjek di sekelilingnya sendiri, sehingga diantara pikiran (mind) dan diri (self) santri menjadi bagian dari tindakan sosial. Santri mendefinisikan dirinya sebagai orang yang sedang belajar agama. Dengan kata lain, santri adalah orang yang memiliki pemahaman agama yang lebih baik daripada orang yang bukan santri. Kemudian tinggal di asrama dengan menjaga dan menjalankan nilai-nilai, norma, etika, dan budaya yang ada di pondok pesantren.

George Herbert Mead mengatakan diri secara dialektis berhubungan dengan pikiran. Tubuh bukan suatu diri dan menjadi suatu diri hanya bila pikiran telah berkembang. Sementara di sisi lain, diri bersama kerefleksifannya, sangat penting bagi perkembangan pikiran. Berpikir merupakan interaksi oleh diri orang yang bersangkutan dengan orang lain. Tidak ada pikiran (mind) yang timbul lepas-bebas dari situasi sosial, namun ia memiliki keterkaitan di mana diri 
(self) berada (Umiarso dan Elbandiansyah, 2014:189-190). Dengan demikian, apa yang menjadi konsep diri (self) santri merupakan hasil dari proses berpikir (mind) yang terkait dengan keberadaan santri di pondok pesantren.

Dalam interaksi sosial muncul pikiran (mind) dan konsep diri (self) aktor yang merupakan bagian esensi dalam tindakan sosial, sehingga mereka saling mempengaruhi menyesuaikan diri dan saling mencocokan tindakan-tindakan mereka. Sebagaiamana santri saat berinteraksi dengan kiainya adalah sebagai tindakan sosial setelah santri melihat bahwa para santri di Pondok Pesantren Al Munawwir Krapyak Yogyakarta memang harus seperti itu dalam melakukan interaksi dengan kiai. Artinya, kesadaran diri terbangun oleh pikiran (mind) santri yang merefleksikan kenyataan sosial di sekitar mereka, sehingga berusaha untuk mencocokkan satu sama lain.

\section{Interaksi Sosial Santri}

Suasana penuh kekeluargaan dan kehangatan tercermin dari interaksi santri dengan kiai di Pondok Pesantren Al Munawwir Krapyak Yogyakarta. Interaksi ini seperti halnya antara orangtua dengan anak. Santri memandang bahwa kiainya adalah orangtua yang dapat menjadi teladan, inspirator, dan selalu menjadi tempat mengadukan berbagai permasalahan yang sedang dihadapi santri. Pola hubungan orangtua-anak di Pondok Pesantren Al Munawwir Krapyak Yogyakarta, tercipta melalui intensitas komunikasi di antara santri dan kiai.

“....kiai memiliki perhatian yang sama dengan orangtua kita. Sampai Alhamdulillah yaa mbah najib sampai hafal satu persatu santrinya, kita nggak perlu nyebutin nama. "Oh.. ini hilmi, bapaknya ini ya? Alamatnya di sini” begitu kata kiai menyebut nama ku ketika bertemu dalam pengajian. Nggak biasanya ada guru yang bisa seperti itu, dengan segitu banyaknya santri, beliau sampai hafal. Kayaknya ini sudah warisan dari kiai-kiai terdahulu. Tidak ada sekat antara kiai dengan santri"
(Informan 2, pada tanggal 26 september 2015, di Krapyak, Bantul)

Kiai memahami posisinya bukan saja sebagai seorang pengajar, melainkan membuka diri kepada siapa pun, termasuk memposisikan dirisebagai orangtua. Kiai yang menunjukan sikap tawadhu' juga merasabahwa sebagai manusia harus bersikap terbuka kepada siapa saja, tidak baik ketika menciptakan sekat yang justru akan menjaga jarak. Jadi, sikap seperti di atas bukan saja semata-mata hanya berdasarkan ajaran agama.

Kendatipun tercipta suasana kekeluargaan, santri tetap menjaga batas-batas yang menjadi wilayah bagi seorang santri. Untuk itu, terdapat perbedaan cara dan bentuk interaksi santri dengan kiai, misalnya penggunaan bahasa, konten pesan, maupun bahasa tubuh.

“..yang pertama sopan, kita harus membedakan antara bahasa teman dengan bahasa ketika berkomunikasi dengan kiai. Misalnya kalau dalam bahasa jawa, ya pakai bahasa jawa karma inggil. Yang kedua, misalnya menjaga sikap, cara duduk atau pandangan mata, misalnya menunduk yaa menunduk.." (Informan 1, pada 26 September 2015, di Krapyak, Bantul)

Ada perbedaan penggunaan bahasa saat saat santri berinteraksi dengan kiai. Hal ini menunjukkan adanya perbedaan struktur sosial di pondok pesantren $\mathrm{Al}$ Munawwir Krapyak Yogyakarta. Dalam hal ini kiai memiliki kedudukan sosial yang lebih tinggi daripada santri, sehingga kemudian mempengaruhi interaksi yang terjadi antara santri dengan kiai.

Dalam perspektif komunikasi, interaksi santri dengan kiai merupakan penyampaian pikiran dan perasaan melalui pesan-pesan tertentu-baik verbal maupun nonverbal secara dua arah. Santri selalu memperhatikan bahasa verbal yang digunakan pada saat berkomunikasi dengan kiai. Santri sebagai komunikator akan menggunakan bahasabahasa yang lembut, sopan, dan mudah dipaham oleh kiai. Sebagai contoh saat santri 
sowan kepada kiai untuk menyampaikan sesuatu, maka pertama-tama santri tidak akan memulai telebih percakapan sebelum kiai yang memulai.

"pas interaksi sama kiai, santri harus menggunakan bahasa yang sopan, lembut, dan gampang dipahami. Biasanya kalau pakai bahasa jawa, ya menggunakan bahasa jawa karma inggil, tapi kalau tidak bias cukup dengan bahasa Indonesia. Selain itu, nada bicaranya nggak terlalu tinggi. Terus nggak banyak bercanda kalau lagi ngobrol sama kiai" (wawancara dengan Hilmi tanggal 26 September 2015)

"santri pada saat berinteraksi dengan kiai sebisa mungkin mengurangi kontak mata langsung. Dan ketika sowan, santri tidak berani memulai pembicaraan sebelum kiai yang memulai, begitu juga saat mengakhiri percakapan.Jadi, santri yang memiliki hajat, maka kemudian disampaikan hajatnya, setelah itu kiai menjawab, memberi nasihan dan saran. Jika hajatnya sudah tersampaikan, santri diam saja, tidak berani pamit atau bagaimana. Jadi diam

Interaksi sosial dalam pandangan interaksionisme simbolik tersusun atas tiga entitas, antara lain: tindakan sosial bersama, bersifat simbolik, dan melibatkan pengambilan peran. Komunikasi terus menerus santri melibatkan pertukaran simbol. Ketika santri berinteraksi dengan kiai, maka secara konstan ia akan mencari petunjuk mengenai tipe perilaku dirinya yang cocok dalam konteks dan pandangan kiainya. Serta juga menginterpretasi simbol-simbol yang dimaksud oleh santri lain. Makna subjektif yang dimiliki santri merupakan varian yang paling utama dalam melakukan tindakan berdasarkan apa yang santri yakini, bukan pada makna yang benarbenar objektif.

\section{Dunia Sosial Santri}

George Herbert Blumer (Umiarso dan Elbandiasyah, 2014: 67-68) menekankan bahwa dunia sosial terbentuk dari aktor- aktor sosial yang saling berinteraksi dan dari tindakan merekadalam hubungannyadengan yang lain. Dunia sosial santri di Pondok Pesantren Al Munawwir Krapyak kemudian menjadi nilai-nilai berdasarkan interaksi sosial santri. Peneliti melihat ada beberapa nilai yang menciptakan dunia sosial santri di PondokPesantren Al Munawwir Krapyak:

\section{Nilai Teosentris}

Nilai pertama yang menjadi keyakinan bagi santriadalah teosentris, yaitu pandangan yang menyatakan bahwa semua kejadian, berproses, dan menuju kepada kebenaran Tuhan. Semua aktivitas yang dilakukan santri dalam mengaji maupun menuntut ilmu adalah sebagaibentuk ibadah kepada Allah.

“.. agama Islam mengajarkan kita untuk hormat kepada siapa pun, apalagi kepada orang yang memiliki pengetahuan agama luas. Orang yang memegang teguh agama, insya Allah hidupnya akan selamat dunia akhirat" (Informan 2, pada 26 September 2015, di Krapyak, Bantul)

Nilai-nilai teosentris tersebut cenderung mengutamakan sikap dan perilaku ukhrawi dan berperilaku sakral dalam kehidupan sehari-hari. Ketika santri bersikap tawadhu' terhadap kiai merupakan suatu bentuk penghormatan, menujukan rasa terimakasih, termasuk keberkahan.

2. Nilai Kesederhanaan

Kehidupan santri di Pondok Pesantren Al Munawwir Krapyak bukan dimaksudkan sebagai bentuk kemiskinan, melainkan berkaitan dengan kemampuan bersikap dan dan berpikir wajar, proporsional, dantidak tinggi hati. Kesederhanaan berarti wajar, tidak berlebih-lebihan atau berkekurangan.

\footnotetext{
"Santri diajarkan untuk hidup sederhana. Tidak boleh berlebihan, juga tidak merasa kekurangan. Harus seimbang hidup ini, mas. Bukankah agama kita juga mengajarkan untuk hidup sederhana, sebab berlebihlebihan adalah sifat syaitan" (Informan 1, pada 26 September 2015, di Krapyak, Bantul)
} 
Santri menciptakan keselarasan hidup di lingkungan sosial pondok pesantren. Artinya bahwa hidup adalah tentang mengenal batasbatas, paham kapan saat untuk menahan diri, dan kapan saat untuk mengekpresikan diri. Hal ini santri lakukan berdasarkan pemahamannya secara spiritual.

\section{Nilai Kearifan}

"Ada sebuah hadits yang menyebutkan bahwa manusia yang berhasil adalah dia yang paling bermanfaat bagi yang lain. Nah, santri menjalani hidup dengan berpegang pada hadits itu. Apalagi kehidupan di pondok pesantren harus mampu berbaur dengan yang lain. Sehingga kita berlomba-lomba dalam kebaikan untuk sesama" (Informan 1, pada 26 September 2015, di Krapyak, Bantul)

Santri melihat kehidupan secara arif. Artinya, menjalani aktivitassehari-hari dengan bersikap dan berpikir rendah hati, sabar, dan taat terhadap tata aturan agama islam. Mencapai tujuan tanpa merugikan orang lain. Kemudian mampu menjadi orang yang bermanfaat bagi kepentingan bersama.

\section{Nilai Kebersamaan}

“..karena kita jauh dari orang tua. Kedekatan diantara santri seperti nggak ada batas. Kalau ada makanan, ya dimakan bareng. Tidur juga bareng. (Informan 3, pada 28 September 2015, di Krapyak Yogyakarta)

Santri biasanya hidup dalam satu atap yang sama, sehingga nilai kebersamaan begitu kentara. Berbagi kepada sesama santri sudah menjadi bagian dari kehidupan sehari-hari. Saling membantu satu sama lain, ketika ada santri mengalami kesusahan, maka sudah barang tentu santri lainnya akan memberi bantuan.

\section{Nilai Kemandirian}

“..karena di pondok pesantren santri hidup jauh dari orangtua, maka harus terbiasa melakukan apa-apa saja sendiri. Misalnya masak, mencuci baju, menyiapkan buku pelajaran harus sendiri. Beda kalau pas di rumah, ada ibu yang ikut bantu, tapi di sini nggak bisa. Semua harus sendiri" (Informan 4, pada 28 September 2015, di Krapyak, Bantul)

Hidup jauh dari orangtua membuat santri harus mampu mengurusdirinya sendiri. Untuk itulah, sudah menjadi hal yang biasa apabila santrimemasak, mencuci baju, merencanakan belajar, dan sebagainya secaramandiri. Nilai ini tidak bertentangan dengan kebersamaan, justru sebaliknya bagian dari nilai tersebut.

6. Nilai Pengabdian

"Kalau di pesantren seperti ini, ikatan santri dengan kiai tidak ada habisnya, bahkan sekalipun sudah jadi alumni, tetap terikat meskipun sudah tua. Tidak ada istilah mantan santri. Sebab santri itu yaa sampai kapan pun santri" (Informan 2, pada 26 September 2015, di Krapyak, Bantul)

Ikatan santri dengan kiai sangat kuat, sehingga ada keyakinan dalam diri santri bahwa mereka tidak akan terputus hubungan dengan kiai. Pengabdian terhadap almamater tumbuh dalam diri santri. Untuk itu, tidak sedikit alumni santri yang kemudian mengajar di pondok pesantren sebagaimana dulu mereka menjadi santri pondok pesantren tersebut.

\section{SIMPULAN}

Santri melakukan komunikasi melalui simbol, lazimnya berupa medium bahasa, santri akan menilai, memberi makna,memutuskan suatu tindakan berdasarkan makna tersebut.Dalam komunikasi, hal ini disebut sebagai proses encoding yang dapat diartikan sebagai kegiatan yang dilakukan oleh santri untuk menerjemahkan pikiran dan ide-idenya ke dalam suatu bentuk yang dapat diterima oleh indera. Bentuk penghormatan, ketaatan, dan loyalitas seperti mencium tangan atau menundukan kepala merupakan hasil dari proses encoding santri karena terjadi dialektika antara diri dan pikiran santri terhadap simbol-simbol kiai dalam interaksi sosial. 
Interaksi sosial santri dilihat sebagai suatu proses pada diri santri untuk membentuk dan mengatur perilaku santritersebut dengan mempertimbangkan ekspektasi orang lain, bisa santrilain maupun kiai, yang menjadi mitra interaksinya. Interaksisosial santri dengan kiai berlangsung dalam suasana penuh kehangatan. Kiai bukan saja sebagai pengajar, melainkan menjadi orangtua bagi santri. Ikatan santri terhadap kiainya sangat kuat, sehingga tidak ada istilah mantan santri dari kiai tertentu. Sementara pesanpesan yang dikirimkan santri berupa verbal dan bahasa tubuh.

Pesan verbal santri kepada kiai seperti berbicara denganpelan, menggunakan bahasa yang sopan, dan tidak banyak bercanda. Sementara bahasa tubuh santri ditunjukan melalui kontak mata yang tidak langsung, tidak membuka percakapan sebelum kiai memulai begitu juga ketika menutup percakapan, dan santri menundukan kepala saat berkomunikasi dengan kiai. Sementara proses decoding santri atas pesan yang disampaikan kepada santri kemudian diinterpretasi ke dalam bentuk yang dapat dipahami, seperti menyetujui apa yang disampaikan, atau melaksanakan perintah kiai. Dengan demikian, santri sebagai penerima pesan melakukan tindakantindakan akibat dari terjadinya interaksi santri dengan kiai.

Dunia sosial santri di Pondok Pesantren Al Munawwir Krapyak Yogyakarta berlandaskan pada pengamatan atas sesuatu yang diekspresikan oleh santri meliputi penampilannya, gerak-gerik, dan bahasa simbolikyang muncul dalam situasi sosial, sehingga pada konteks ini dunia sosial pondok pesantren bisa dikatakan merupakan produk dari individu-individu yang dipandang sebagai aktor yang bersifat aktif. Santri menciptakan dunia sosial yang kemudian melahirkan nilai-nilai moral di Pondok Pesantren AlMunawwir Krapyak Yogyakarta, seperti: nilai teosentris, nilai kesederhanaan, nilai kebersamaan, nilai kearifan, nilai kemandirian, dan nilai pengabdian. Nilainilai tersebut tentu berdasarkan pada pemaknaan santri terhadap situasi objek yang menciptakan dunia simbolik di Pondok Pesantren Al Munawwir Krapyak Yogyakarta. 


\section{DAFTAR PUSTAKA}

Ardianto, Elvinaro. 2010. Metode Penelitian untuk Public Relations: kuantitatif dan Kualitatif. Bandung: Simbiosa Rekatama Media

Danesi, Marcel. 2011. Pesan, Tanda, dan Makna: Buku Teks Dasar Mengenai Semiotika dan Teori Komunikasi. Yogyakarta: Jalasutra

Dhofier,Zamakhsyari.1982. Tradisi Pesantren: Studi tentang Pandangan Hidup Kiai. Jakarta: $\mathrm{LP}_{3} \mathrm{ES}$

Haryanto, Sugeng. 2012. Persepsi Santri Terhadap Perilaku Kepemimpinan Kiaidi Pondok Pesantren: Studi Interaksionisme Simbolik di Pondok PesantrenSidogiri Pasuruan. Jakarta: Kementerian Agama RI

Idrus, Muhammad. 2009. Metode Penelitian Ilmu Sosial. Yogyakarta: Erlangga

Littlejohn, Stephen W. \& Keren A. Foss. 2009. Teori Komunikasi. Jakarta: Salemba

Majid, Nurcholis. 1997. Bilik-Bilik Pesantren: Sebuah Potret Perjalanan. Jakarta: Paramadina

Mufid, Muhammad. 2010. Etika dan Filsafat Komunikasi. Jakarta: Kencana Pernada Media Group

Mulyana, Deddy. 2008. Komunikasi Efektif: Suatu Pendekatan Lintasbudaya. Bandung: PT Remaja Rosdakarya

Mutalimah. 2003. "Model Pembaharuan Sistem Pendidikan Pesantren Salaf di PP. Al Munawwir Krapyak Yogyakarta." Skripsi. Fakultas Tarbiyah InstitutAgama Islam Negeri Sunan Kalijaga Yogyakarta.

Kriyantono, Rachmat. 2010. Teknik Praktis Riset Komunikasi: Disertai Contoh Praktis Riset Media, Public Relations, Advertising, Komunikasi Organisasi, Komunikasi Pemasaran. Jakarta: Kencana
Prawito, 2007. Penelitian Komunikasi Kualitatif. Yogyakarta: LKiS

Riyanto, Waryani Fajar \& Mokhamad Mahfud. 2012. Komunikasi Islam (I).Yogyakarta: Galuh Patria

Rochman, Agus Ghozali. 2008. Peran Kepemimpinan Kiai dalam MeningkatkanMutu Pendidikan Pesantre: Studi Kasus Pondok Pesantren KomplekNurussalam Al Munawwir Krapyak Yoyakarta.Skripsi. Fakultas Tarbiyah UIN Sunan Kalijaga Yogyakarta

Ruben, D. Brent dan Lea P. Stewart. 2013. Komunikasi dan Perilaku Manusia. Jakarta rajawali Press

Sugiyono, 2008.Memahami Penelitian Kualitatif. Bandung: Afabeta

Suranto AW. 2011. Komunikasi Interpersonal. Yogyakarta: Graha Ilmu

Umiarso dan Elbandiasyah. 2014. Interaksionisme Simbolik Dari Era Klasik Hingga Modern. Jakarta: PT Raja Grafindo Persada

Tarmizi. 2010. Pola Interaksi Antar Umat Beragama dalam TeoriInteraksionisme Simbolik Masyarakat Agama (Studi Kasus di Sorowajan).Skripsi. Fakultas Ushuluddin UIN Sunan Kalijaga Yogyakarta

Widodo, Suko. 2010. Anatomi dan Perkembangan Sosial. Malang: Aditya MediaPublishing

W. Syam, Nina. 20o9. SosiologiKomunikasi. Bandung: Humaniora

Darno. 2010. "Rambut Gondrong dalam Konteks Kode Etik Mahasiswa UIN SunanKalijaga Yogyakarta (Menurut Perspekstif Interaksionisme Simbolik)”. Skripsi. Fakultas Ilmu Sosial dan Humaniora UIN Sunan KalijagaYogyakarta 